\title{
SCENARIO ANALYSIS IN THE CALCULATION OF INVESTMENT EFFICIENCY- THE PROBLEM OF FORMULATING ASSUMPTIONS
}

\author{
Iwona Dittmann, PhD \\ Faculty of Finance \\ University of Economics in Wroctaw \\ e-mail: iwona.dittmann@ue.wroc.pl
}

\begin{abstract}
This article concerns the problem of formulating assumptions in scenario analysis for investments which consist of the renting out of an apartment. The article attempts to indicate the foundations for the formulation of assumptions on the basis of observed retrospective regularities. It includes theoretical considerations regarding scenario design, as well as the results of studies on the formulation, in the past, of quantities which determined or were likely to bring closer estimate the value of the individual explanatory variables for a chosen measure of investment profitability $\left(M_{\left.I R R_{F C F E}\right)}\right.$. The dynamics of and correlation between the variables were studied. The research was based on quarterly data from local residential real estate markets in Poland (in the six largest cities) in the years 2006 - 2014, as well as on data from the financial market.
\end{abstract}

Key words: real estate market, investment efficiency, scenario analysis.

JEL Classification: R3, G11, G17.

Citation: Dittmann I., 2015, Scenario Analysis in the Calculation of Investment Efficiency - the Problem of Formulating Assumptions, Real Estate Management and Valuation, Vol. 23, No. 3, pp. 54-64.

DOI: 10.1515/remav-2015-0025

\section{Introduction}

One of the forms of investing on the real estate market is purchasing an apartment to rent out. The low interest rates on loans in Poland in the years 2004 - 2007, along with the prevailing belief in the continuous upward trend in housing prices, sparked great interest in such a form of investment. Profitability and risk analyses of various forms of real estate investments were conducted in scientific literature (inter alia, WOLSKI, ZAŁĘCZNA 2007, pp. 105-118; CRONE, VOITH 1999, pp. 63-78). On the other hand, it can be assumed that only a portion of the investors independently performed a full (i.e. including risk measurement) ex ante calculation of the efficiency of such an investment, and only a few - did so using the scenario analysis method (see KUCHARSKA-STASIAK 2006, p. 118). Failure to carry out investment risk assessment by the investor can, it seems, result from the lack of appropriate knowledge and skills necessary to perform it, or from unrealistic optimism and overconfidence.

This article attempts to indicate the foundations of the formulation of assumptions for scenario analysis on the basis of observed retrospective regularities.

\section{Scenario analysis}

Investment decisions are made based on efficiency calculations carried out ex ante, within which the expected return on an investment, as well as risk, are studied. One of the analyses performed when calculating an investment's efficiency is scenario analysis. It belongs to a group of deterministic simulation methods, that is those consisting of repeating the procedure of calculating the value of the accepted measure of investment efficiency (e.g. NPV, IRR, MIRR) for the different values of variables 
that affect the measure of investment profitability. The possibility of simultaneously studying the impact of numerous variables on an investment's profitability is considered an advantage of scenario analysis. As a result, a possible range of variation in investment efficiency (calculated according to the criterion used), depending on the changes in the input parameters, is obtained. Importantly, this analysis can and should take into account the relationships which occur between the independent explanatory variables (ROGOWSKI 2013).

Faults pointed out in scenario analysis include the fragmentary nature of risk assessment as well as problems in the formulation of scenarios (ROGOWSKI 2013; MINASOWICZ 2009). This fragmentation is due to the fact that only a limited number of scenarios are considered. The fundamental problem in scenario construction is the difficulty in the formulation of assumptions regarding the evolution of variables impacting investment efficiency for each individual scenario. It is assumed that the values adopted by the independent explanatory variables present in the algorithm of the accepted efficiencymeasuring criterion (e.g. NPV, IRR, MIRR) can, within a specified range and with varying probability, differ from the values of those variables adopted in the baseline scenario. According to literature on the subject-matter, scenario analysis should take into account a range of the most likely values of explanatory variables (BRIGHAM, GAPENSKI 2000), or the full range of possibilities (DAMODARAN 2009).

It is worth noting that the construction of scenarios can be based on forecasts for individual variables influencing the profitability of the investment. In scenario creation, point forecasts and, in particular, interval forecasts (e.g. constructed taking into account possible forecast error) are useful. Point forecasts can be useful in constructing the most likely scenario. The lower and upper limits of interval forecasts can form the basis of the construction of extreme scenarios (optimistic and pessimistic). Alternative forecasts, constructed under different assumptions concerning, e.g. the financial structure of the investment (LTV level), can also be a useful tool for creating scenarios. (DITTMANN 2011, p. 85).

When constructing scenarios (and determining their number) it seems that it is worth taking into account that:

1) In the case of some variables, a small percentage change in their value can have a significant impact on the profitability of the investment. These variables can be identified for a given criterion of profitability (e.g., NPV, IRR, MIRR) through a sensitivity analysis (see, inter alia, Bełej, Cellmer 2006). It is worth constructing individual scenarios for the different potential values. However, in the case of variables with a low impact on the profitability of the project, the number of scenarios can be limited to one.

2) Point forecasts of some variables are burdened with larger errors than point forecasts of other variables. This can result from, e.g., a lack of historical data, the high volatility in the value assumed by the variable in the past, the high sensitivity of the variable to macroeconomic factors, political factors, etc. For such variables, it is worth constructing interval and alternative forecasts, and, subsequently, individual scenarios on their basis. In the case of variables whose point forecasts are not encumbered with significant error (e.g., due to low volatility), one (baseline) scenario should be sufficient.

3) Some variables may be characterized by interdependence.

Literature indicates three methods of constructing holistic (combined) scenarios, as being composed of the scenarios of individual explanatory variables (DITTMANN 2011, pp. 87-89). The first method is based on joining the scenarios of explanatory variables according to a "round robin" principle. The disadvantage of this solution is its disregard for the relationships between the explanatory variables, resulting in substantively flawed combined scenarios. The second method assumes a combination of the scenarios of explanatory variables, taking into account previously identified relationships (regularities) between the explanatory variables. In constructing combined scenarios, knowledge of economics, market-specific economics (e.g. of the real estate market), valuation (e.g., of real estate) and appropriate statistical analysis (regarding variable correlation) is useful. The third method consists of building individual scenarios on the basis of uncontrolled, controlled, and dependent variables. Uncontrolled variables are defined as variables which the decision maker has no influence over; their value is independent of any decisions made by him (e.g WIBOR, interest rates). Controlled variables are variables whose value is determined by the decision maker's decisions (e.g. the amount of a loan taken out). Dependent variables are those variables whose values depend on the decisions made by the decision maker (e.g., the surface area rented 
depends on the amount of rent demanded) (SZPULAK 2010, pp. 219-220; SZPULAK 2003, p. 204). A disadvantage is the difficulty of classifying some variables, e.g. rent paid by the tenant ultimately depends on the owner, but is also largely dependent on market conditions.

In the case of the construction of three basic scenarios (optimistic, baseline and pessimistic), the investor obtains three different possible rates of return. If the rate of return calculated in the pessimistic scenario is higher than the rate of return required by the investor, then the obvious decision to make is the decision to invest. If in the baseline scenario (i.e. the most likely to occur) the expected rate of return is lower than the rate required by the investor, then he should reject that investment. It is often the case that the rate of return calculated for the baseline scenario is higher than the required rate, but the rate calculated for the pessimistic scenario is lower than the required rate. In this case it is worth proposing: 1) the formulation of several intermediate scenarios (i.e. worse than the baseline but better than the originally assumed pessimistic scenario) and an assessment of the rate of return obtained in the case of their realization; 2) the calculation of the safety margins and profitability thresholds with regard to individual variables, in order to assess the investment risks; 3 ) an estimation of the probability of the realization of the original pessimistic scenario.

\section{MIRR $_{\mathrm{FCFE}}$ as a measure of the profitability of investing in an apartment for rent}

Different measures may be used to evaluate the profitability of investments. Literature indicates a breakdown of profitability measures:

1) static or dynamic;

2) based on an accounting approach or in terms of cash;

3) in FCFF or FCFE formulas (inter alia, ROGOWSKI 2013).

Static measures are constructed on the basis of the size of the given (single) investment year, or on the average from several years, and do not take into account the variability of the values in individual years, or the change in the value of money over time. The static measure is a simple rate of return which can be calculated, e.g. as: the average annual net profit on investment expenditure; the average annual cash flow on investment expenditure, or the average annual cash flow on investment expenditure increased by the capital gains obtained on the investment expenditure at the end of the investment. Dynamic measures take into account the variability of the values in individual years as well as the change in the value of money over time. These include, for example: internal rate of return (IRR), modified internal rate of return and net present value (NPV).

Measures representing an accounting approach are based on data coming from the profit and loss account. They include, for example: annual net profit to assets, annual net profit increased by capital gains at the end of investment to equity. Measures based on the cash approach are based on cash flows. These include, for example: annual cash flow to investment expenditure, internal rate of return based on cash flows (IRR), modified internal rate of return based on cash flows (MIRR), net present value. Because cash flows have a higher significance for the investor than does profit (HENCLEWSKA 2004), the cash-based approaches to measures are recommended.

Measures of profitability can be calculated through the use of different net cash flow calculation formulas. The most commonly used formulas are the classic formula - FCFF (free cash flow to firm) and the ownership formula (free cash flow to equity). In the FCFF formula, investment and operational flows are taken into account, however financial flows are not considered (e.g. loan servicing costs). Income tax is calculated based on the operating profit (thus the tax shield related to loan servicing costs is not taken into account). The discount rate reflects the rate of return required by all suppliers of capital and is counted as the weighted average of capital cost (WACC). In the FCFE formula investment flows, operational flows and financial flows alike are taken into account. The income tax is estimated on the basis of actual taxable income. The discount rate is based on the rate of return required by the owner (at the cost of personal equity) (ROGOWSKI 2013).

From the many available measures of the profitability of investments, modified internal rate of

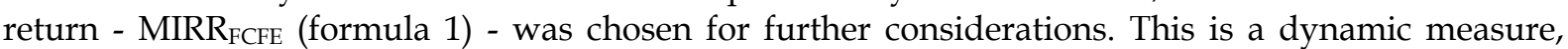
based on cash flow in the FCFE formula. It is thus the appropriate measure, from a financial point of view, for investments which last over a year, with multiple flows, including investments consisting of the renting out of an apartment. It should be noted, however, that in the case of the unmodified

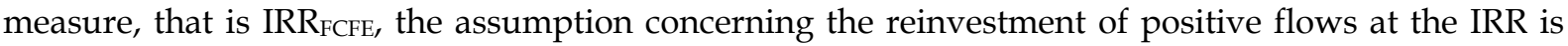
not met. MIRR $R_{\mathrm{FCF}}$ resolves this problem. MIRR is easy to apply; its formula is accessible in Excel. 


$$
M I R R=\sqrt[n]{\frac{\sum_{t=0}^{n} C F A T_{t}^{"+"}\left(1+k_{\text {rei }}\right)^{n-t}}{\sum_{t=0}^{n} \frac{\left|C F A T_{t}^{--"}\right|}{(1+k)^{t}}}}-1
$$

where:

$C F A T_{t} "+"$ - positive net cash flow in period $\mathrm{t}$

$C F A T_{t}{ }^{\prime-}$ - $\quad$ negative net cash flow in period $\mathrm{t}$

$\mathrm{k}_{\text {rei }}$ - rate of reinvestment

$\mathrm{k}$ - discount rate

In MIRR $_{\mathrm{FCFE}}$ it can be assumed that the positive net cash flow generated by the investment is reinvested at an interest rate resulting from current market opportunities (this is the concept of external rate of return). In the article, it was assumed that this can be equal to the annual interest rates on bank deposits. The discount rate can be determined based on the cost of personal equity, and this may be due to, inter alia, the rate of return on alternative investments - therefore it may be different for different investors.

\section{Retrospective analysis of the shaping of selected variables}

For the purposes of efficiency calculations conducted for the investment in an apartment for rent, the investor should respond in particular to the following questions: what price will he sell the property for? What rental rate will he obtain in the individual years of the investment? How high will the mortgage installments he will pay be? What will the rate of return on reinvestment of the positive net cash flow be (using MIRR $\mathrm{FCFE}_{\text {)? }}$ In the case of scenario analysis, the answers can be captured either as a range or as alternatives.

This article examines the formulation, in the past, of quantities determining or able to bring closer the values of individual explanatory variables. It was accepted that on the basis of the data obtained, e.g. dynamics, an attempt could be made to construct optimistic and pessimistic scenarios. WIBOR 3M was accepted as the variable which was responsible for the shaping of the value of mortgage loan installments. The average annual interest rate on bank deposits in Poland was accepted as the variable determining the formation of the rate of reinvestment. The average transactional rental rate for $1 \mathrm{~m}^{2}$ of space in specific Polish cities was accepted as the variable which allowed for the calculation of the rental income. The average transactional price for $1 \mathrm{~m}^{2}$ of space, corrected for the hedonic index on the secondary market in specific cities, was accepted as the variable allowing for an estimation of the selling price. The second portion of the analysis concerned the correlations between the explanatory variables - an important issue when combining the scenarios for various individual explanatory variables.

The analyses were conducted on quarterly data for the time period from 3Q of 2006 until 3Q of 2014 (for the rental rates - a time period from 3Q 2006 until 1Q 2014). The data from local markets encompassed 6 cities: Gdańsk, Cracow, Łódź, Warsaw and Wrocław. The source of the data was a report and the database of the Polish National Bank (AUGUSTYNIAK et al. 2013, www.nbp.pl/home.aspx?f=/statystyka/ pieniezna_i_bankowa /oprocentowanie_n.html) as well as a financial service (stooq.pl).

In order to answer the question: what selling price (at the end of the investment) can be assumed in individual scenarios? the price dynamics of $1 \mathrm{~m}^{2}$ of apartment space on local secondary markets in the past were examined. The relative increases of the average transaction price for $1 \mathrm{~m}^{2}$ of space were calculated, adjusted for the hedonic index of the secondary market for various investment periods (minimum 1 quarter, maximum 32 quarters), assuming various moments of the start of the investment. On this basis, for each of the cities examined, 32 box plots representing the distribution of changes in transaction price on the secondary market for investments from 1 quarter to 32 quarters in length were constructed (Fig. 1). The plot for the investment lasting one quarter arose on the basis of 32 observations, the plot for the half year investment - on the basis of 31 observations, etc. The plots for the longest investment periods arose on the basis of limited data, e.g. the "plot" for 8 years consists 
of one observation. It should be acknowledged that these plots cannot form a foundation for scenario construction. On the basis of the plots relating to Gdańsk, in the case of the 6-year investment, a 16\% fall in the price could be noted in the baseline scenario (as compared to the current price); in the case of the optimistic scenario, a $2 \%$ price increase was identified, and for the pessimistic scenario, a $30 \%$ price decrease was noted. It is worth taking into account the variable distribution for time periods encompassing a different number of quarters (especially those slightly shorter and slightly longer than the expected period of investment).

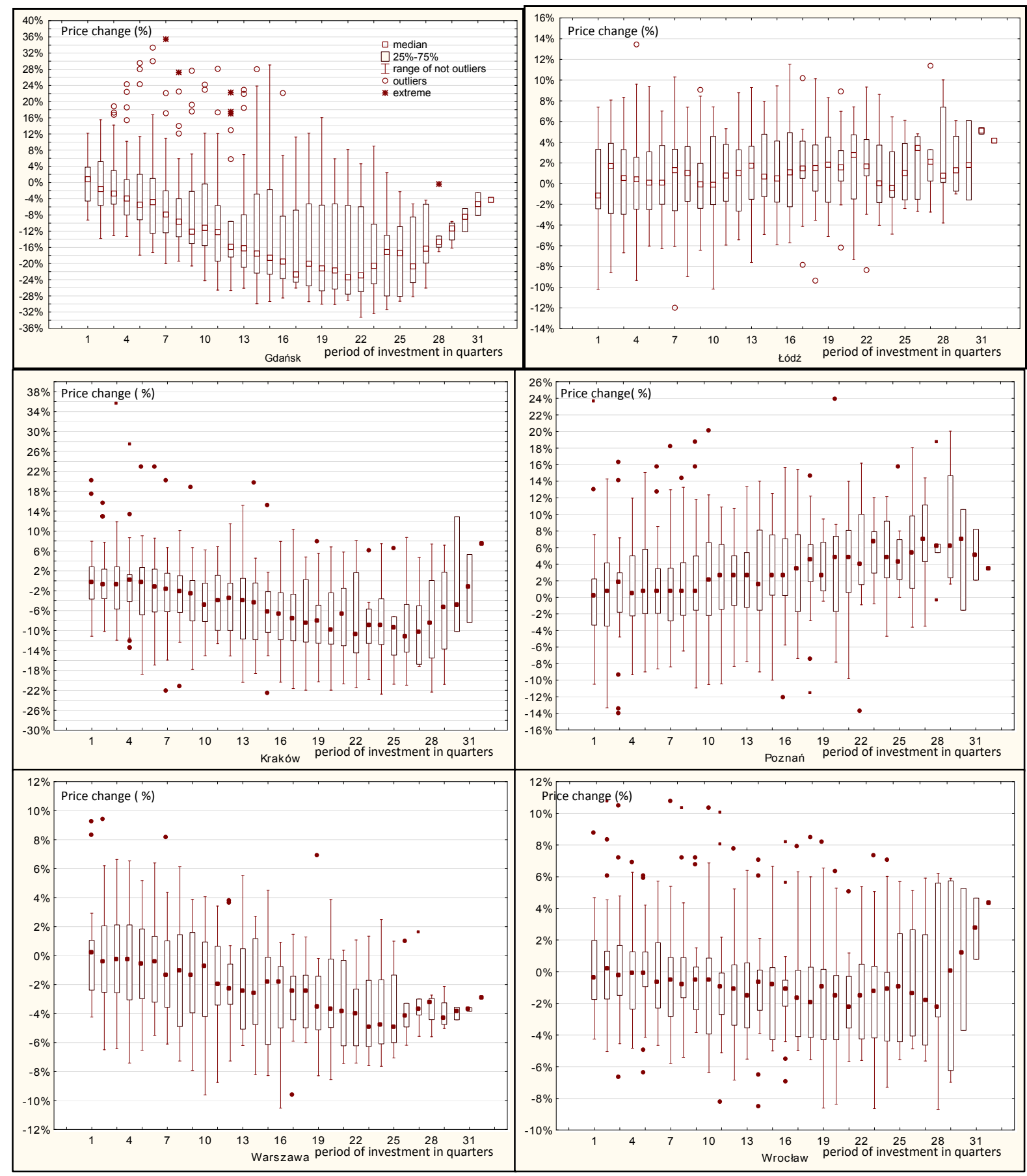

Fig. 1. Distribution of changes in transaction prices. Source: own calculations based on (AUGUSTYNIAK et al. 2013).

Doubts concerning the concept of using the presented results in scenario construction should, however, be noted. Firstly, it must be emphasized that the prices assumed for the analyses are average prices on a given local market, adjusted for the hedonic index. However, in the case of a specific 
apartment, the volatility of its price on the secondary market may be wholly different. Secondly, the prices did not take into account the increasing degree of wear of the apartments, which should be considered in the form of an appropriate price adjustment. Thirdly, price increases demonstrate price dynamics on the secondary market; therefore, if the apartment were to be purchased on the primary market, an additional price adjustment should be performed. Lastly, the time period assumed for the studies (3Q 2006 to 3Q 2014) is too short - it does not encompass the full economic cycle, thus distorting the results, especially since investments in apartments for rent often last longer than 8 years. It is also worth noting that the longer the investment time period, the lower the impact of the expected real estate selling price on the MIRR FCFE value (cf. ŻELAZOWSKI 2014, p. 48).

In order to answer the question of how to differentiate different scenarios based on the rental rate as well as its dynamics throughout the investment period, average rental rates of $1 \mathrm{~m}^{2}$ of residential space in specific cities were examined, and appropriate plots were constructed (Fig. 2).

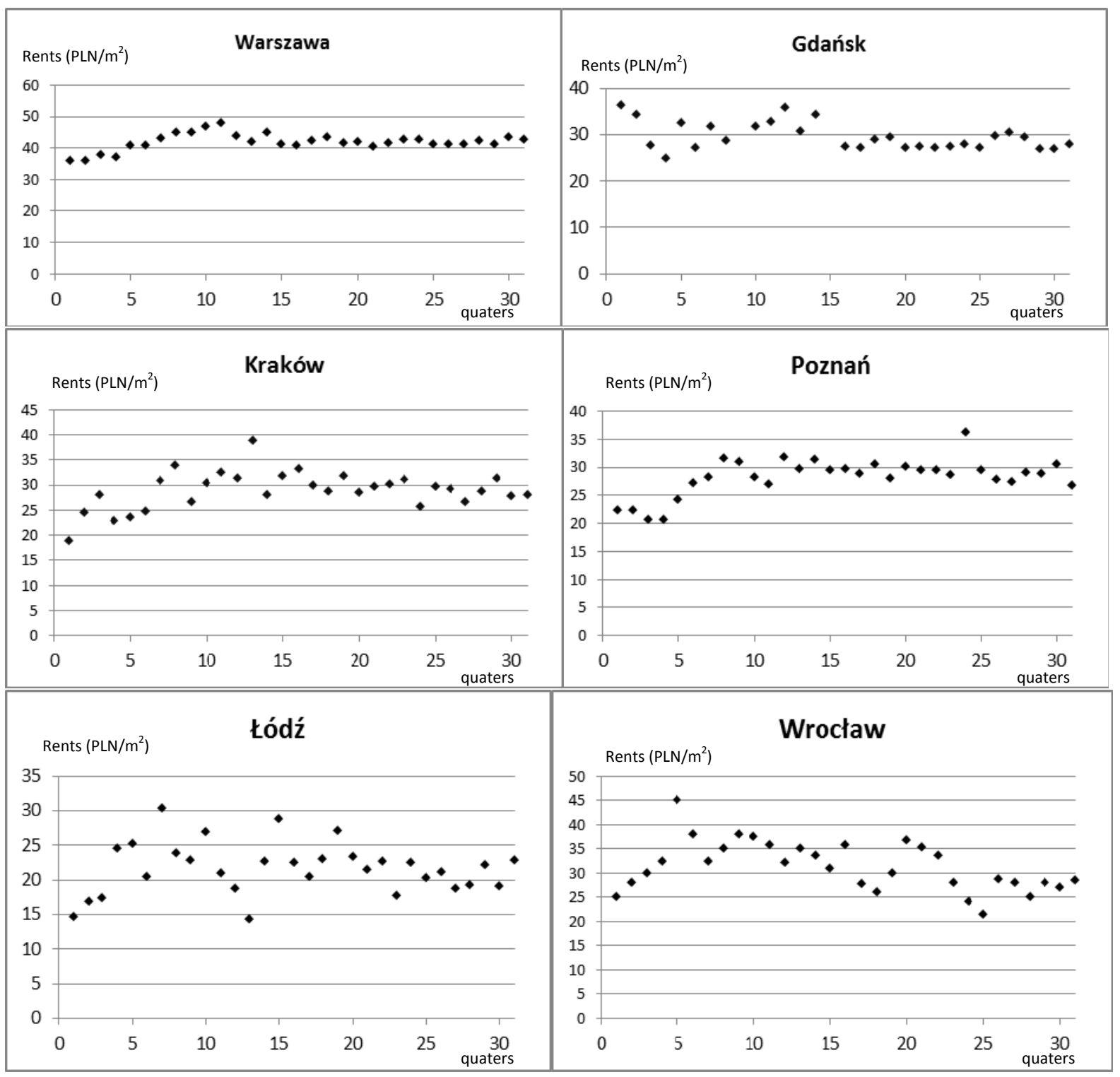

Fig. 2. Average transaction rental rates of $1 \mathrm{~m}^{2}$ of residential space. Source: own calculation based on (AUGUSTYNIAK et al. 2013).

Based on the obtained results, it can be concluded that the time period under investigation was characterized by a visibly high volatility in rents. For example, in Warsaw, the rental rate in 1Q 2009 was higher than the rental rate in 3Q 2006 by 33\%, and subsequently fell. In 1Q 2014 it was lower than in 1Q 2009 by 12,5\%. An even greater volatility characterized the rates in the remaining cities. In Cracow, an increase in rental rates of 50\% (as compared to 3Q 2006) was maintained for the vast 
majority of the examined period. Gdańsk, however, was characterized by a downward trend. A constant decrease in rental rates can be observed in the last 15 quarters, amounting to around $22 \%$ when compared with 3Q 2006. When constructing scenarios for this variable, the data presented should be referred to.

Three problems, however, should be noted. Firstly, the analyses are based on average rental rates, calculated for the given local market on a quarterly basis. In the case of renting an apartment, however, the agreed upon rent is usually constant for an annual period, and sometimes for even longer. Secondly, the rental rate and its dynamics in the case of a specific apartment can differ from the average, thus in the case of each city, a more precise analysis is indicated (taking into account the rental rates in the given location and for the given apartment standard). Thirdly, the rates used in the analysis are not adjusted for the hedonic index, thus their differentiation in time can also be due to differences in quality between the proposed premises.

In order to answer the question of what mortgage payment installments to assume in individual scenarios and what dynamics for them, relative increases (individual and chain) of WIBOR 3M were calculated in the time period from 3Q 2006 to 3Q 2014 (Fig. 3). It can be argued that the individual quarters were characterized by significant differences in WIBOR 3M rates. For this reason, constructing the pessimistic scenario for this variable should assume its marked increase $(40 \%-60 \%)$ compared to the current rate. In the optimistic scenario, decreases of even $50 \%$ should be considered. In the short term, both dynamic changes from quarter to quarter as well as periods of relative stability (e.g. 3Q 2009-1Q 2011) were observed. It is worth emphasizing that in order to assess the likelihood of individual scenarios, the current level of WIBOR 3M should be taken into account (e.g. a low WIBOR $3 \mathrm{M}$ rate allows for the assumption of a greater likelihood of increase or stabilization rather than decrease).

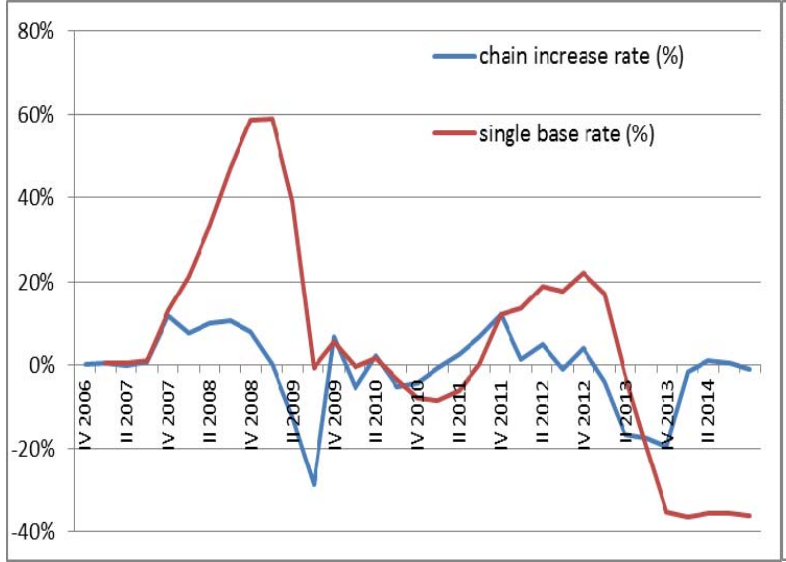

Fig. 3. WIBOR 3M: relative chain-type and single-base increases. Source: own calculations based on (www.stooq.pl/q/?s=plopln3m).

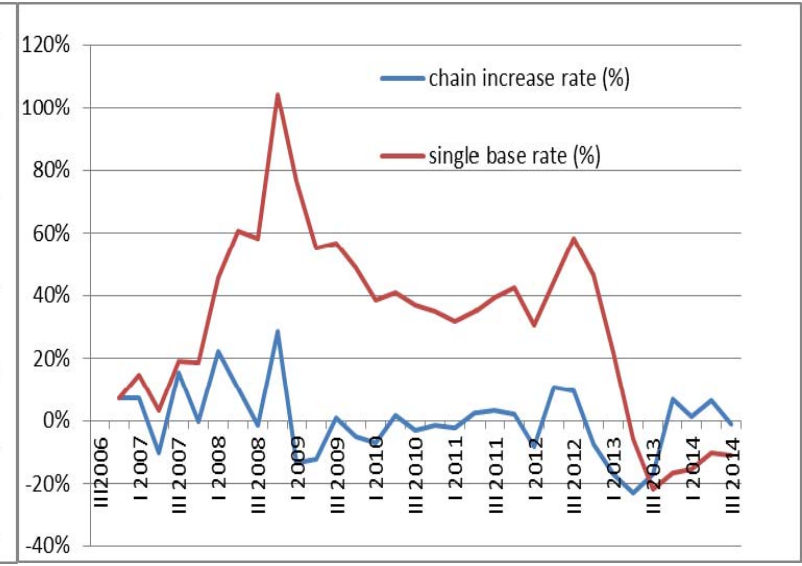

Fig. 4. Interest rates on bank deposits: relative chain-type and single-base. Source: own calculation based on (www.nbp.pl/home.aspx?f= /statystyka/pieniezna_i_bankowa/oprocentowa nie_n.html).

To answer the question: what interest rates on bank deposits should be adopted for individual scenarios and what dynamics for them?, the dynamics of interest rates on bank deposits were examined for the time period from 3Q 2006 until 3Q 2014 (Fig. 4). It can be noticed that the changes in the interest rates on bank deposits in the studied time period were higher than in the case of the changes in WIBOR 3M . The average interest rate on deposits in 3Q 2006 amounted to $3.1 \%$, then it rose up to $6.4 \%$ in 4Q 2008 (Fig. 5) - the change exceeded 100\%. The decrease in 3Q 2014 as compared to $4 \mathrm{Q} 2008$, however, amounted to over $50 \%$. Thus, in constructing scenarios for longer time periods for this variable, it is also worth taking into account the wide range of variation. For shorter time frames, as in the case of the WIBOR 3M rates, both dynamic changes and periods of stabilization could be observed.

When combining the scenarios for particular explanatory variables into a holistic scenario, the interdependence of the explanatory variables is an important issue. In order to examine it, the correlation coefficients for the adopted variables were calculated and graphs were constructed (Figs. 5, 
$\left.6^{1}\right)$. It was determined, first of all, that, in line with expectations, there was a high correlation between the WIBOR $3 \mathrm{M}$ rate and the interest rate on bank deposits (the correlation coefficient amounted to 0.83). This means that neither scenarios in which both an increase in the WIBOR 3M and a decrease in interest rates on bank deposits, nor scenarios which assume a simultaneous decline in WIBOR 3M rates and increase in interest rates on bank deposits, should be constructed. Since in the MIRR model the WIBOR 3M is a deterrent, and the reinvestment rate - a stimulant, it can be concluded that thanks to the high correlation of these variables, the combined scenarios will be less extreme. In the case of the remaining variables, a lack of a clear interdependence was observed. Both quarters which were characterized by an increase in all variables and a decrease in all variables, as well as quarters showing increases in some variables and decreases in others can be indicated (Fig. 6). Goodchild, analyzing the cyclical nature of the real estate market in Great Britain in the years 1968-2013 also pointed out the occurrence of time periods of: 1.) increases in rent and simultaneous increases in the value of real estate; 2.) decreases of rent and simultaneous decreases in the value of real estate; 3 .) increases in rent and concurrent decreases in the value of real estate; 4.) decreases in rent and concurrent increases in the value of real estate (GOODCHILD 2014). This means that in the construction of combined scenarios, both extreme scenarios (e.g. pessimistic, with a simultaneous decrease in the selling price, decrease in rent and decrease in interest rates on deposits) as well as intermediate scenarios (e.g. an increase in selling price, decrease in rent and increase in the interest rate on deposits) should be taken into account.

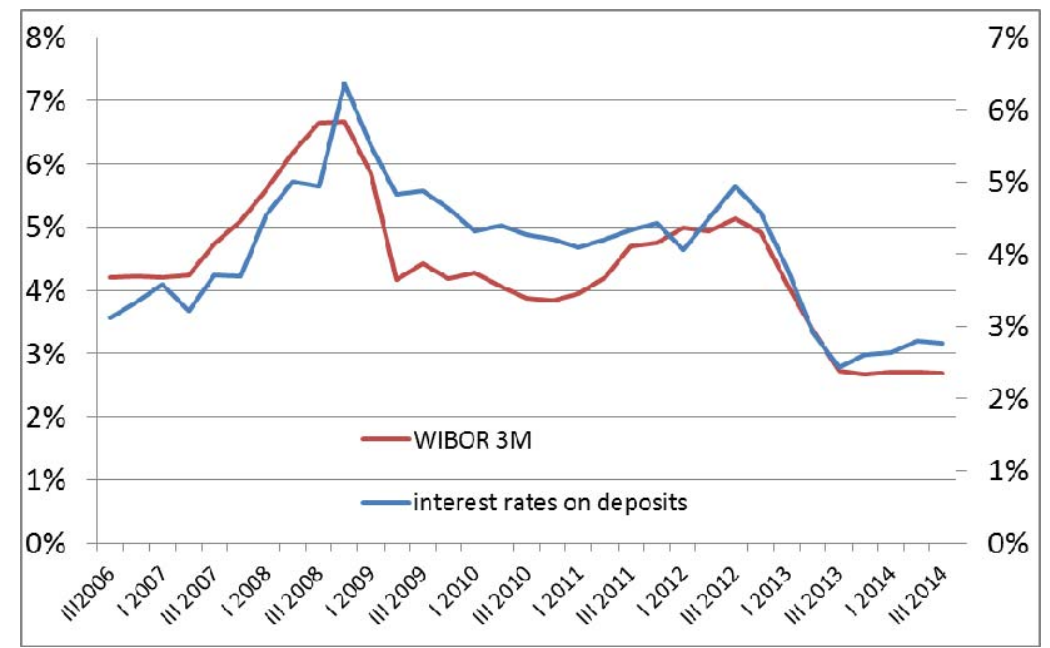

Fig. 5. Interest rates on bank deposits (right axis) and WIBOR 3M (left axis) in the time period from 3Q. 2006 to 3Q 2014. Source: own elaboration on the basis of (www.nbp.pl/home.aspx?f=/statystyka/ pieniezna_i_bankowa/oprocentowanie_n.html, www.stooq.pl/q/?s=plopln3m).

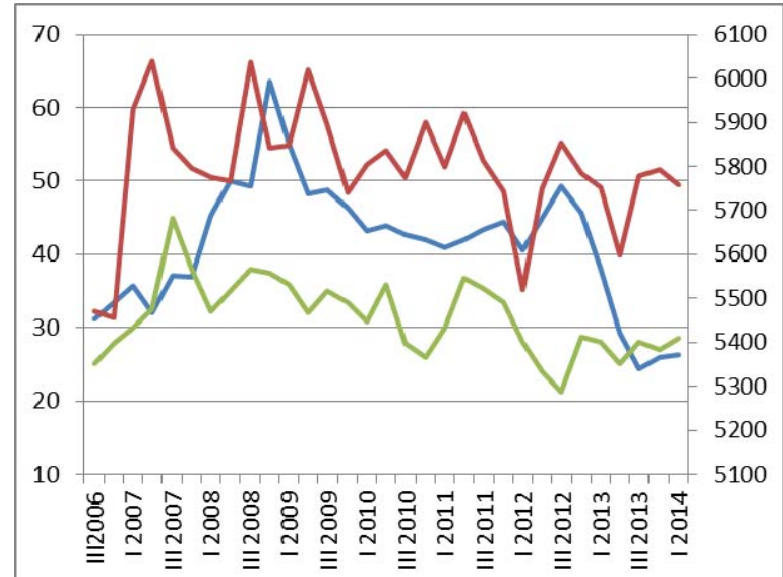

-interest rate on deposit*1000

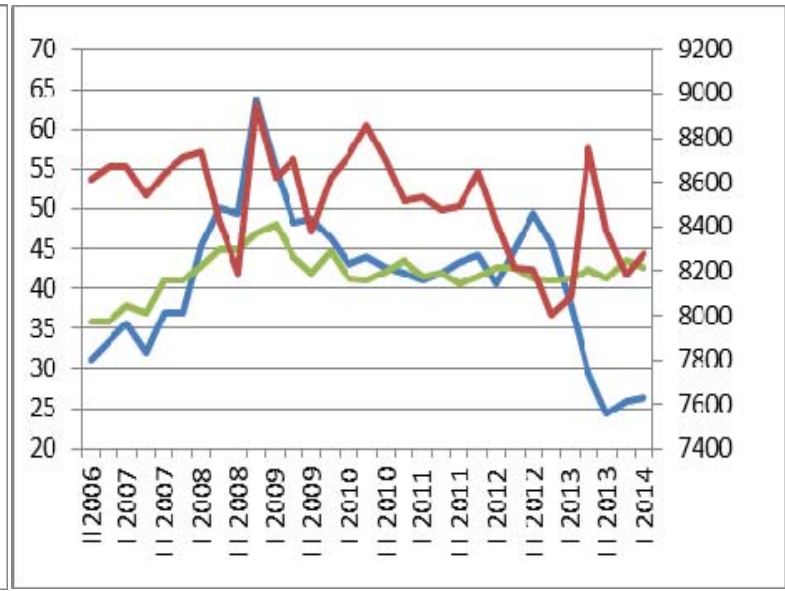

—Interest rate on deposit" $1000-$ rent (PLN) — price (PLN)

\footnotetext{
${ }^{1}$ The data on rents in some cities were incomplete.
} 
Wrocław

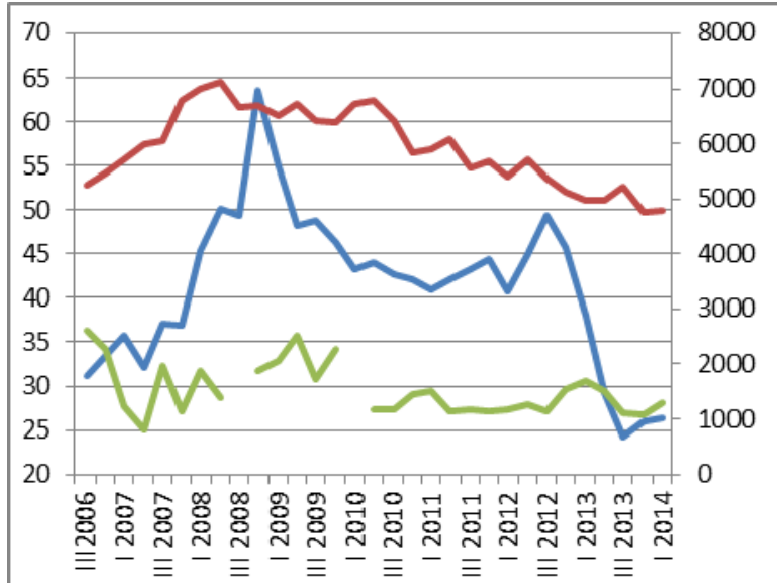

-interest rate on deposit*1000 -rent (PLN) — price (PLN) Gdańsk

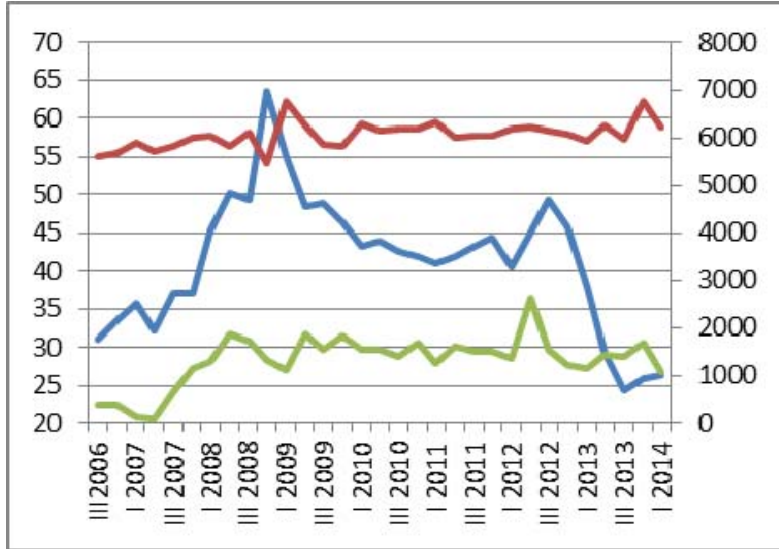

—interest rate on deposit*1000

Poznań
Warsaw

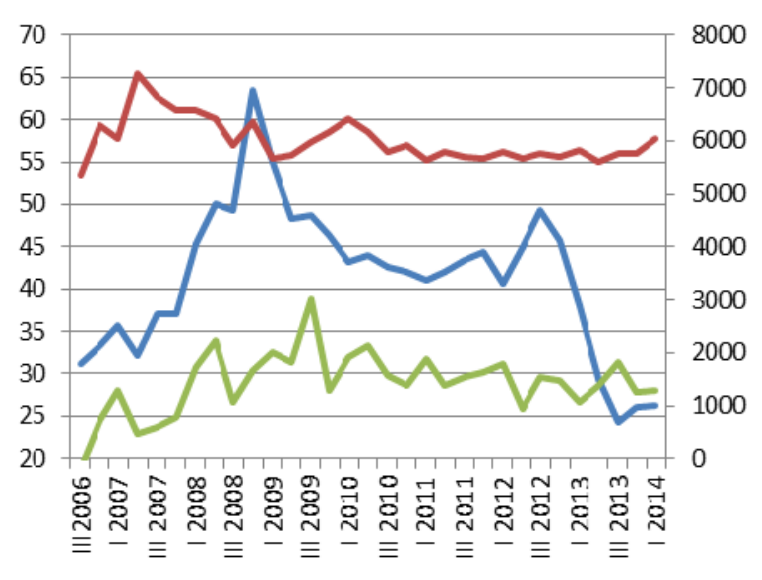

interest rate on deposit*1000 Cracow

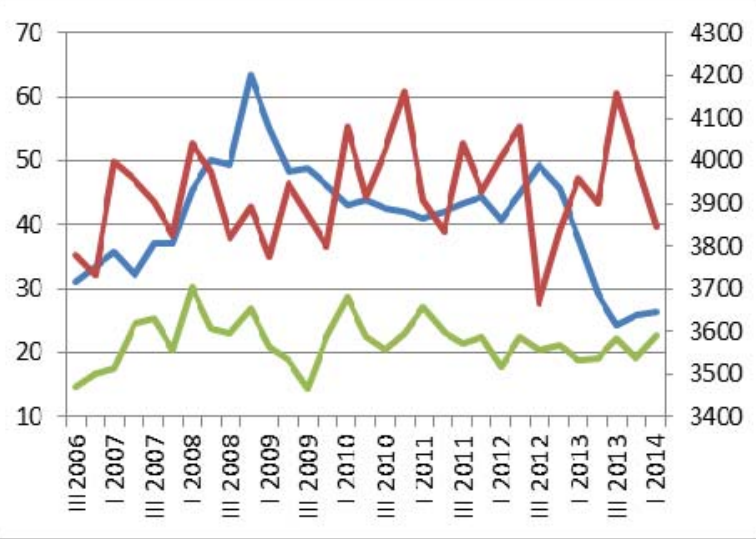

interest rate on deposit*1000 rent (PLN) — price (PLN)

Łódź

Fig 6. Price of $1 \mathrm{~m}^{2}$ of apartment space in PLN (right axis), average apartment rental rates in specific

cities in PLN $/ \mathrm{m}^{2}$ and the average interest rate on bank deposits Times 1000 (left axis) in the time period between 3Q 2006 to 1Q 2014. Source: own elaboration on the basis of (AUGUSTYNIAK et al. 2013, www.nbp.pl/home.aspx?f=/statystyka/pieniezna_i_bankowa/oprocentowanie_n.html).

\section{Conclusion - summary of the results}

Statistical methods are often used in the study of the real estate market (see, inter alia, FORYŚ, GDAKOWICZ 2004, pp. 41-49; FORYŚ, GDAKOWICZ 2006, pp. 335-342; ZHOU, HAURIN 2010, pp. 377-395; GU 2002, pp. 213-233). The retrospective regularities discovered can serve to predict the evolution of events in the future. It should be noted, that the suggestion of using historical data in scenario analysis which is presented in this article is not the only possible concept. In scenario construction, it is worth using different modeling and forecasting methods widely described in literature. The possibility of modeling and forecasting the price of real estate or rental rates of residential dwellings was studied by, inter alia: BARAŃSKA 2004 pp. 5-16; BARAŃSKA 2008, pp. 33-45; BERACHA, WINTOKI 2013, pp. 283-312; MUCZYŃSKI et al. 2007, pp. 177-185; LI, ROSENBLATT 1997, pp. 81-104; WIŚNIEWSKI 2007. It is worth adding that in the case of the analysis of the risk involved in investing in residential real estate, demographic indicators and the growing saturation of the market for rental housing should, in particular, be taken into account.

In the article, the possibility of taking into account retrospective regularities when constructing scenarios was demonstrated. However, as was emphasized in the article, the assumed research period was quite short. This resulted from the availability of data concerning local real estate markets. The applicability of the results obtained based on a time series which does not encompass the full economic cycle can raise doubts. More useful would be an analysis conducted on the basis of a longer 
time period, e.g. 16 years, due to the long term nature of investments on the real estate market. It seems that it can be accepted, however, that the time period is sufficient for pessimistic and baseline scenario construction, as the predominant portion of the studied time period was characterized by economic downturn and stabilization on the real estate market. And for an investor, scenarios which take into account risk in terms of the negative aspect (pessimistic) are more important than those considering the positive aspect (optimistic).

It is worth noting that in the case of investments financed by a mortgage in a foreign currency (e.g. CHF, EUR) an important variable influencing the profitability of the investment is the exchange rate. It can be subject to strong fluctuations, and at a high LTV ratio, dramatically change the profitability of the investment. Thus, the investor financing the real estate through a loan in a foreign currency should also examine the variability in LIBOR and the CHF exchange rate, or the EURIBOR and EUR exchange rate. In this article, such an analysis was not undertaken, as the S Recommendation from June 2013, changing the conditions for the granting of foreign currency loans starting in July 2014, made it virtually impossible for Polish investors to incur mortgages in foreign currencies.

\section{References}

AUGUSTYNIAK H., ŁASZEK J., OLSZEWSKI K., WASZCZUK J., 2013, Raport o sytuacji na rynkach nieruchomości mieszkaniowych i komercyjnych w Polsce w 2013 r. (Report on the situation on the residential and commercial property market in Poland in 2013. (dostęp: http://www.nbp.pl/ publikacje/rynek_nieruchomosci/raport_2013_miasta.pdf).

BARAŃSKA A., 2004, Przygotowanie bazy danych o nieruchomościach na potrzeby modelowania matematycznego wartości rynkowej (Preparation of real estate data bases for mathematical modelling of market value), Studia i Materiały Towarzystwa Naukowego Nieruchomości, Vol. 12, No. 1, Olsztyn, pp. 5-16.

BARAŃSKA A., 2008, Jakościowo-ilościowe metody rynkowej wyceny nieruchomości (Quality and quantity methods market valuation of real estates), Studia i Materiały Towarzystwa Naukowego Nieruchomości, Vol. 16, No. 3, Olsztyn, pp. 33-45.

BeŁej M., CELlmer R., 2006, Koncepcja oceny poziomów ryzyka na rynku nieruchomości $i$ sposoby jego uwzgledniania w procesie inwestycyjnym (The concept of levels of risk assessment on the property market and how to take into account the investment proces), Studia i Materiały Towarzystwa Naukowego Nieruchomości, vol. 14, nr 1, Olsztyn, pp. 13-26.

Beracha E., WintoKi M. B., 2013, Forecasting Residential Real Estate Price Changes from Online Search Activity, Journal of Real Estate Research, Volume 35, Number 3, pp. 283-312.

BRIGHAM E.F., GAPENSKI L.C., 2000, Zarządzanie finansami (Finance management), Warszawa, PWE

CRONE, T.M., VOITH R.P, 1999, Risk and Return within the Single-Family Housing Market, Real Estate Economics, 27:1, pp. 63-78.

DAMODARAN A., 2009, Ryzyko strategiczne: podstawy zarzadzania ryzykiem (Strategic risk: the basics of risk management), Warszawa, Wydawnictwa Akademickie i Profesjonalne, Akademia Leona Koźmińskiego.

DiTTMANN I., 2011, Forecasting in constructing scenarios for assessing profitability and risk of investing in real property, Research Papers of Wrocław University of Economics No. 196 "Econometrics", 32, Wrocław, pp. 83-91.

FORYŚ I., GDAKOWICZ A., 2004, Wykorzystanie metod ilościowych do badania rynku nieruchomości (The use of quantitative methods to study the real estate market), Studia i Materiały Towarzystwa Naukowego Nieruchomości, Vol. 12, No. 1, Olsztyn, pp. 41-49.

FORYŚ I., GDAKOWICZ A., 2006, Rynek nieruchomości mieszkaniowych w Polsce - wykorzystanie metod taksonomicznych (Residential real estate market in Poland - the use of taxonomic methods), Prace Naukowe Akademii Ekonomicznej im. Oskara Langego we Wrocławiu, No. 1126. Taksonomia, pp. 335-342.

GOODCHILD R., 2014, How property markets work: some lessons learned over three cycles. European Real Estate Society conference paper, unpublished (presentation available at: http://eres.architexturez.net/system/files/pdf/eres2014_208.content.pdf).

Gu A.Y., 2002, The Predictability of House Prices, Journal of Real Estate Research, 24:3, pp. 213-233

HeNClEWSKA L., PIĘTA J.K., MARCHWICKA W., LiBERA L., 2004, Plany zarządzania nieruchomościami: teoria i praktyka (Plans for property management: theory and practice), Warszawa, C.H.Beck. 
Li Y., Rosenblatt E., 1997, Can Urban Indicators to Predict Home Price Appreciation: Implications for Redlining Research, Real Estate Economics, 25:1, pp. 81-104.

KUCHARSKA-STASIAK E., 2006, Ryzyko inwestowania na rynku nieruchomości (The risk of investing in real estate), Studia i Materiały Towarzystwa Naukowego Nieruchomości, Vol. 14, No. 1, Olsztyn, pp. 109-122.

MiNASOWICZ A., 2009, Efektywność i zarządzanie finansami w budownictwie (Efficiency and financial management in the construction industry), Poltext, Warszawa.

MuCZYŃSKI A., MiJALSKA K., SUJKOWSKI Z., 2007, Modelowanie czynszów najmu lokali mieszkalnych $i$ użytkowych na rynku nieruchomości (Modeling of rents apartments and commercial premises on the real estate market), Studia i Materiały Towarzystwa Naukowego Nieruchomości, Vol. 15, No. 3-4, Olsztyn, pp. 177-185.

ROGOWSKI W., 2013, Rachunek efektywności inwestycji: wyzwania teorii i potrzeby praktyki (Account of investment efficiency: the challenges of theory and practice needs), Warszawa, Oficyna a Wolters Kluwer business.

SZPUlAK A., 2003, Proces prognozowania w przedsiębiorstwie na przykładzie prognozowania przeptywów pieniężnych (Forecasting process in the enterprise on the example of cash flow forecasting), Prace Naukowe Akademii Ekonomicznej nr 1001, Wrocław, pp. 203-215.

SZPUlAK A., 2010, Prognozowanie a planowanie finansowe w przedsiębiorstwie (Forecasting and financial planning in a company), Prace Naukowe Uniwersytetu Ekonomicznego nr 103, UE, Wrocław, pp. 218-225.

WIŚNIEWSKI R., 2007, Wielowymiarowe prognozowanie wartości nieruchomości (Multivariate prediction of the value of property), Seria: Rozprawy i monografie, Olsztyn, Wydawnictwo Uniwersytetu Warmińsko-Mazurskiego.

WolSKI R., ZAŁĘCZNA M., 2007, Mieszkanie jako alternatywna inwestycja (Housing as an alternative investment), Studia i Materiały Towarzystwa Naukowego Nieruchomości, Vol. 15, No. 3-4, Olsztyn, pp. 105-118.

www.nbp.pl/home.aspx?f=/statystyka/pieniezna_i_bankowa/oprocentowanie_n.html www.stooq.pl/q/?s=plopln3m.

ZHOU Y., HAURIN D., R., 2010, On the Determinants of House Value Volatility, Journal of Real Estate Research, Vol. 32, No. 4, pp. 377-395.

ŻELAZOWSKI K., 2014, Significance of Residual Value in Asset Valuation, Real Estate Management and Valuation, Vol. 22, No. 1, pp. 47-53. 